\title{
Correction to: Treatment of Psoriasis with Secukinumab in Challenging Patient Scenarios: A Review of the Available Evidence
}

\author{
Jashin J. Wu · Joseph F. Merola $\cdot$ Steven R. Feldman • Alan Menter •
}

Mark Lebwohl

Published online: May 18, 2020

(C) The Author(s) 2020

Correction to: Dermatol Ther (Heidelb) https://

doi.org/10.1007/s13555-020-00373-z

The authors would like to correct the error in Table 1, where under $\mathrm{HBV} / \mathrm{HCV}$ it reads as follows:

- HBV/HCV: Immunosuppressive therapies must be given prior to secukinumab...

The "immunosuppressive" should be revised to "antiviral" for clarity with the rest of the statement in the table. Hence, the line should be corrected as follows:

- HBV/HCV: Antiviral therapies must be given prior to secukinumab...

The original article can be found online at https://doi. org/10.1007/s13555-020-00373-z.

J. J. Wu $(\bowtie)$

Dermatology Research and Education Foundation, Irvine, CA, USA

e-mail: jashinwu@gmail.com

Open Access. This article is licensed under a Creative Commons Attribution-NonCommercial 4.0 International License, which permits any non-commercial use, sharing, adaptation, distribution and reproduction in any medium or format, as long as you give appropriate credit to the original author(s) and the source, provide a link to the Creative Commons licence, and indicate if changes were made. The images or other third party material in this article are included in the article's Creative Commons licence, unless indicated otherwise in a credit line to the material. If material is not included in the article's Creative Commons licence and your intended use is not permitted by statutory regulation or exceeds the permitted use, you will need to obtain permission directly from the copyright holder. To view a copy of this licence, visit http://creativecommons.org/licenses/by$\mathrm{nc} / 4.0 /$.

J. F. Merola

Brigham and Women's Hospital, Harvard Medical

School, Boston, MA, USA

S. R. Feldman

Department of Dermatology, Wake Forest School of

Medicine, Winston-Salem, NC, USA

A. Menter

Baylor Scott \& White Health, Dallas, TX, USA

M. Lebwohl

Mount Sinai Hospital, New York, NY, USA 